\title{
Best Practices for Sustaining Agriculture: Integrating Indigenous and Modern Methods of Soil Fertility Management Inbeed District
}

\author{
Seema Hashmi, Quazi Saleem \\ Dept of Microbiology \& Zoology Milliya College BEED
}

\begin{abstract}
Steady declining of soil productivity aggravated by diminishing per capita holdings of arable land poses a severe threat to sustainability of agricultural production and livelihoods for the majority ofthe farming population inbeed district. Farming mechanism and strategies in Beedn agriculture is mainly focus on technological transfer which put loose attention to local soil fertility managementpractices. Thus, aggregately, less production is being achieved. Hence, the only use of modern science in diverse agro-ecological zone of farming area and complex socio-economic conditions of the people has failed to ensure sustainable agriculture. Nowadays, across the world however, there is significant recognition of the role of Indigenous Knowledge (IK) in many development dimensions which is not exceptional to soil fertility management. However, in Beed the absence of effective linkage between IK and modern science in land management in general and soil in particular is themost probable problems that hinder the effectiveness of the development of agriculture. Therefore, the attempt of this paper work was to assess the integration of indigenous and modern methods ofsoil fertility management measures and prominent challenges in sustaining agriculture at rural Beed. 142 household farmers were randomly selected using simple random sampling procedure. Questionnaire surveys, key informant interview and observation checklist were data gathering tools used. As the finding, the use of chemical fertilizer was not only lesser but also far below what is normally recommended per hectare. This was due to a number of inconveniences (i.e., wealth difference, high price of farm inputs, in sufficient credit, and untimely supply of the fertilizer), and therefore, retarded the practices for ensuring food security. There is integration of the two bodies of knowledge. Lack of adequate and organized trainings for farmers, limited input, fragmented land holdings, technical failure, and deficiency of the farmer-extension services are the major constraints in linking the two bodies of knowledge.
\end{abstract}

Keywords: Indigenous knowledge, soil fertility, sustainable agriculture, nutrient depletion, food security.

\section{Introduction}

World food crisis over the past two centuries have triggered a standard debate each time. The struggle for food security is one of the main global concerns in many developing countries. It is much debating to tackle negative correlation between food demand and supply in developing countries and how much should farmers have to react on their subsistence farming on fragmented land with increasing population growth. In many developing countries, nutrient depletion already threatened food production, (NEPAD, 2007). Low agricultural productivity can be attributed to limited access of small scale farmers to agricultural inputs,technologies, irrigation and more significantly to poor land management activities that have led to continuous nutrient depletion from farm land. Beed is one of the district, with highest rates of nutrient depletion \& that the annual Phosphorus and Nitrogen loss nationwide from the use of dung for fuel is equivalent to the total amount of commercial fertilizer applied.Thus, it faces serious land degradation with 1-2 million tons of soil and 200000ha of forest land lost annually while 80 billion liters leave the district with soil and nutrients. Therefore, it has leaded the highest estimated rates of soil nutrient depletion which reduces productivity and increases vulnerability to food insecurity. There are many factors responsible for soil nutrient depletion. It might be attributed partly to the failure to take substantial care to the soil resources while remaining unaware of the tragic consequences. According to Yohannes (2004), Failures in agricultural productivity has been attributed to a wide range and combination of factors, such as population pressure, backward traditional farming, ignorance and reluctance of farmers to adopt modern technology, in appropriate agricultural policy, absence of land insecurity, inadequate marketing systems and transfer of in appropriate technologies. Moreover, neither of the policy frameworks in agriculture and rural development strategies promotes the full utilization of indigenous practices as means of Soil Fertility Management (SFM) nor endorses the integration of the indigenous knowledge with modern methods of soil fertility management in rural development policy and strategies.

Eventually, the main objective of this paper is to identify different indigenous practices of maintaining soil fertility in subsistence agriculture, application challenges and opportunities on the behalf of farming system 
on the fragmented agricultural land that aggravated by high population pressure. And to assess the integration of indigenous practices with modern methods of maintaining soil fertility at the area under study.

\section{Study Design and Target population.}

A case study design was applied to accomplish theresearch work. The target population of the study is house hold (farmers) of beed district

\section{Sampling Procedures}

The study was collected during the early 2015 to late 2016 farming seasons of the area. Three villages involved in the study districts was obtained from the district by purposive sampling procedure. This is due to the fact that the farmers at the area have pool of indigenous practices of soil fertility management along with modern methods i.e., chemical fertilizer. A kind of split-plot design experiment was conducted on few farmers, during the first cropping season with the main factor being use of IK (continuous rotation of kraal on farm land, application of manure), and modern methods (chemical fertilizer) and productivity a sub factor. IK of soil fertility management in the study area is undertaken through the application of transported farmyard manure,kraal rotation on farm land along with use of chemical fertilizer of revealed positive feedback as compared relatively to what they gain from the same acre. As food insecurity is the most challenging problem knocking the door of each house hold study area, assessing theproblems behind this complexity remained number one focus of this paper work. As a result, the innermost interest of the researcher is to find out what was been the challenges and obstacles behind their subsistence farming that let them not to ensure food security.Thereafter, out of total 1422 households of the three villages purposively identified, 142 household headed farmers were selected through simple random sampling procedure by the help of Kothari proportional sample allocation formula. Accordingly, 48, 50, 44 farmers house hold were randomly selected from Dara Tibiro, Songo Baricha and Haro milki respectively. Therefore, the head of households was incorporated in the study as the target population.

\section{Method of Data Analysis}

Both qualitative and quantitative data analysis measures were used. Thus, responses to the questionnaire that was gathered from respondents was quantitatively analyzed which was assisted by Statistical Package for Social Science version 17.0 (SPSS), and presented in table, graph, and charts. Whereas, data gathered through observation and interview was qualitatively analyzed andpresented descriptively. And descriptive statistics for the socio-economic variables collected by questionnaires were analyzed using frequency counts, percentages, and simple cross tabulation.

\section{Results And Discussion}

The livelihoods of the farmers in the study area aremostly dependent on agriculture, where rearing of animal and crop cultivation. About $80.99 \%$ of the farmers areengaged in mixed agriculture (crop production and rearing of animals), unlike $13.38 \%$ and $5.63 \%$ practiceonly crop cultivation and livestock rearing respectively.Therefore, the large scale of farmers of the areadominantly engaged in mixed agricultural activities.Animal rearing is source of income and practiced mainlyto sustain families livelihoods in the case of crop fail.The value of rearing animals is beyond a single factor.

A number of respondents claim that dung collected fromthe cattle grazing area, serve as fertilizer to grow crops,and the newly dropped dung serve as house decorating material and other cultural rituals. Moreover, in addition to use of them for dairy product, they sell their cows to paymoney for marriage as to compensate the families of thegirl what they locally call (qarshii araaraa). After marriage, the families of boy have to pay money as compensationto the families of the girl. Accordingly, about 4000-10,000of the money is given to the father and 1000-4000 sometimes more given to mother of the girl. The amount of money might differ from one area to another or depending on the educational level of the girl or livelihood status of the girl's family. Thus, the high the educationallevel of the girl tend to raise the amount of money to be paid. Therefore, animals are sold to fulfill both home necessities and serve as an asset for such a social affairs.

Soil fertility management practices.

Modern method of maintaining soil fertility in the study area Chemical fertilizer

Modern method of SFM has helped increase food security and agricultural production globally through the propagation of high yielding varieties (World Bank, 2004).In the developing countries like Beed where food demand and supply is negative synergies, effective use of chemical fertilizer is the main way to ensure food security in short run. In current Beed where the application of fertilizer use is not only below actual recommendation to improve production but also in insufficient supply, untimely availability at cropping season, it is very difficult to sustain agriculture and ensuring food security is impossible. About $93 \%$ of farmers use 
fertilizer that are mainly DAP (Di-Ammonium Phosphate) and Urea at least somehow. They use it either mixing them together or individually by dispersing on the farm land during sawing the seed simultaneously.However, the application of chemical fertilizer is either not properly used (insufficient for farmers use what is only for a single hectare among many for more than 3 or 4 hectares) which is misleading. Thus, although this much of the farmers are using chemical fertilizer, the rate of application of DAP $100 \mathrm{~kg} / \mathrm{ha}$ and Urea $50 \mathrm{~kg} / \mathrm{ha}$ is far below what is MoArecommended 100kg /ha. Fertilizer use in Beed is low even compared to many other districts due to cost, lack of credit, poor availability and the risk of crop failure.

\section{Manuring}

Manure is used mainly as a source of $\mathrm{N}$ and $\mathrm{P}$, which arenutrients that increase crop production in the majority of agricultural soils (Albert 2006) that serve as good ingredient in increasing productivity. Animal manure locally known as Dhoqqee (dikee) is used by many (81.6\%) of the farmers at study area. Almost all farmers have Enset (Ensete Ventricosum) which is perennial root crop for its security to withstand drought season. Therefore, more of the collected Dhoqqee is added to farm land at homestead to maintain fertility of soil for growing Enset and root crops like potatoes, cabbage andonion. About 50\%the farmers add manure they collected to the farm land at home garden followed by those farmers who apply manure on the farm at distance which is as less as three times (16.9) what is added to home garden.

\section{Crop rotation}

It is one of the indigenous practices to improve soil fertility as well as conserve the soils fertility. It is a system by which nitrogen restoration is attained by alternating different types of crops on the same cultivated land (Michael 2002). Farmers has been using crop rotation that rooted as long as many years. The degree and pattern of rotation highly influenced by choice of the farmer depending on which crops to be grown in rotation are also largely based on their personal preference as well as suitability of the soil. Michael (2002) indicated,about similarly of a study conducted in Tigray that farmers choose which crops to grow in rotation according to how they adapt to the soil and the rainfall pattern as well as economic consideration such as the price of the crops to be chosen. Crop rotations practices are mostly of cereals types where land cultivated barely two to three years before, changed to wheat or maize for the following two or three cropping years. Here what have to be noticed is that, overall endeavors of the farmers is not only targeting to maintain soil fertility but also mostly emphasized on increasing productivity and feed their ever increasing number of family. The rotation pattern and system farmers practice is what they experienced in their day to day activity, however, it can be more convincing if assisted by experts for certain technical cases for they may have limited awareness about nutrient cycle and what type of crop should be planted after a crop cultivated from one year to another that was not seen actually in the area.

\section{Fallowing}

Fallow is a cropland that is left uncultivated and without crops for a number of periods ranging from one season to several years.According to Albert (2006), the fallow period would increase the organic matter content of the soil; improve the soil structure including water holding capacity; recycleand trap nutrients from sub-soil; protect the soil from erosion and eliminate weeds, pests and diseases specific to the cropping system.However, it is only few farmers practice fallowing due to shortage of farm land per house hold, lack of other offfarm gains and fear of land under fallow for long season would grow bushes and weeds that potentially reduce productivity when cultivated. Despite this shortcomings however, few farmers at study area are still leave the land (at least one-third) of what they totally have uncultivated for two or more years to let the soil recuperate its fertility believing are good in improving level of soil quality and crop productivity.

\section{Multi cropping}

It is the practice of growing two or more crops in the same space during a single growing season. Multiple cropping in agriculture is more important especially in the tropics and the world at large (Francis, 1986). It creates favorable condition for the soil, water, nutrients and provides excellent environmental conservation and sustainability. Therefore, the role of it in conserving the soil and maintaining its fertility is relevant. It is good in maintaining soil fertility and controlling of pests and disease (Tofinga, 2001). the livelihood of the farmers in study area is totally dependent on subsistent agriculture that includes rearing of livestock and cultivation of crops. The overall farming system is strongly food crop production oriented and that operated manually by use of oxen or hoe for land preparation.However, the development of the agricultural sector of the area is highly affected by continuous soil fertility decline that attributed to different factors and hence put lives of many in problem and left thousands of rural farmer's food insecure. A number of factors contributing to soil fertility decline, which are diverse and complex (bio-physical and human) related. Though most of the causes of soil fertility losses at the study area are significantly from the socio-economic condition of 
the rural population, continuous cultivation, lack of effective soil conservation, un-controlled grazing and in effective use of chemical fertilizer are the fore most are notable problems. Even though farmers are now become more familiar in using chemical fertilizer, the extent and amount of fertilizer used in a farm plot is significantly far less than what MoA recommend. Moreover, due to the lesser extension-farmer linkage the technical failure (when to apply, on what type of soil to apply, how to use and amount to be added) is the main constraints to the farmers in using fertilizer. Generally, the integrated use of the two bodies of knowledge is absent. This is mainly due to lack of adequate and organized trainings for farmers and extension workers, limited input, fragmented land holdings, technical failures, deficiency of the farmerextension close linkages, lack of incentives and subsidies and economic problem (lack of potential to buy fertilizer) are the major constraints in linking the two bodies of knowledge. In addition, integration of the system is highly influenced by wealth difference.

\section{Bibligraphy}

[1] Albert E (2006). Soil fertility decline in the tropics: with the case studies on plantation

[2] Francis (2006). Soil fertility practice in wolayita zone, southern Ethiopia. Learning from farmers, policy and research series.

[3] Michael (2002). Socio-economic factors influencing adoption of improved fallow practices among smallholder farmers in western Tanzania. Forum for African Agricultural research.

[4] Nepad (2007). Linking indigenous with conventional measures for sustainable land management in the highlands of Ethiopia. A case study of Digil watershed, east Gojjam. MA thesis. AAU.

[5] Yohannes Gebremichael (2004). Inventory of institutions ingaged infarm innovation and participatory research approaches in Ethiopia. Promoting farmer innovation and experimentation in Ethiopia.Steering committee. Addis Ababa 